\title{
Implementing the Netherlands Code of Conduct for Scientific Practice-A Case Study
}

\author{
Daan Schuurbiers · Patricia Osseweijer • \\ Julian Kinderlerer
}

Received: 27 October 2008/Accepted: 28 December 2008/Published online: 21 January 2009

(C) The Author(s) 2009. This article is published with open access at Springerlink.com

\begin{abstract}
Widespread enthusiasm for establishing scientific codes of conduct notwithstanding, the utility of such codes in influencing scientific practice is not self-evident. It largely depends on the implementation phase following their establishment - a phase which often receives little attention. The aim of this paper is to provide recommendations for guiding effective implementation through an assessment of one particular code of conduct in one particular institute. Based on a series of interviews held with researchers at the Department of Biotechnology of Delft University of Technology, this paper evaluates how the Netherlands Code of Conduct for Scientific Practice is received by those it is supposed to govern. While respondents agreed that discussion of the guiding principles of scientific conduct is called for, they did not consider the code as such to be a useful instrument. As a tool for the individual scientific practitioner, the code leaves a number of important questions unanswered in relation to visibility, enforcement, integration with daily practice and the distribution of responsibility. Recommendations are provided on the basis of these questions. There is more at stake than merely holding scientific practitioners to a proper exercise of their duties; implementation of scientific society
\end{abstract}

D. Schuurbiers $(\bowtie) \cdot$ P. Osseweijer $\cdot$ J. Kinderlerer

Working Group on Biotechnology and Society, Department of Biotechnology,

Delft University of Technology, Julianalaan 67, 2628 BC Delft, The Netherlands

e-mail: d.schuurbiers@tudelft.nl

D. Schuurbiers

Centre for Society and Genomics, Nijmegen, The Netherlands

P. Osseweijer

Kluyver Centre for Genomics of Industrial Fermentation, Delft, The Netherlands

J. Kinderlerer

Department of Intellectual Property Law, University of Cape Town,

Cape Town, South Africa 
codes of conduct also concerns the further motives and value commitments that gave rise to their establishment in the first place.

Keywords Code of conduct - Science and engineering ethics $\cdot$ Responsible conduct of research · Research integrity - Moral responsibility

\section{Introduction}

Scientific and engineering codes of conduct have received a considerable amount of attention over the last decades: several hundreds of codes, pledges and oaths can be found on the web. The UNESCO Global Ethics Observatory [1] has registered 151 codes of conduct related to science and technology worldwide, and this is probably just a fraction of the total number of codes produced in recent years.

Whereas scientific associations often have high expectations of such codes in regard to raising awareness of the principles that the profession endorses [2], the mere establishment of codes of conduct may not always lead to the expected outcomes [3]. Codes of conduct do not necessarily support their stated intentions, and may, when they appear superficial or strategic, even work against them [4]. Whether codes of conduct achieve their aims is dependent on the aims and intentions with which they are produced, the way they are received and taken up by the members of the professional community, continuing efforts to discuss and reflect on them, and the involvement of relevant stakeholders outside the professional community. The implementation phase is thus at least as important as their establishment. This phase, however, often receives little attention. How is the code taken up by the scientific community that it addresses? What are scientists to make of a code of scientific practice once it has landed on their desks? And how can it be integrated with ongoing practices? The aim of this paper is to address these kinds of questions for one particular code of conduct in one particular place.

The Netherlands Code of Conduct for Scientific Practice [5] will be used as a case study. This code of conduct, which was established in 2005, distinguishes itself from other codes in the Netherlands by addressing scientific practice in general. Furthermore, it is to be implemented in universities throughout the Netherlands and was therefore considered an appropriate object of study. The Department of Biotechnology of Delft University of Technology (TU Delft) was chosen as the locus for evaluation. The research in this department focuses on living micro-organisms, the cell and its components. It employs 22 permanent scientific staff, 12 laboratory technicians and 85 temporary researchers (PhD's, post docs, etc.). Research areas include analytical biotechnology, bioseparation technology, biocatalysis and organic chemistry, enzymology, bioprocess technology, industrial microbiology and environmental biotechnology. The department was considering implementation of the code of conduct at the start of this study. Whilst good scientific conduct in the case of research on either animals or humans is ethically sensitive for obvious reasons, research on micro-organisms is much 
less publicly controversial. Researchers' willingness to discuss the norms of scientific conduct can therefore be expected not to arise from a perceived need to appease public concerns which means the results may apply in other fields of research as well. Based on a series of interviews held with researchers at the department, this paper will evaluate how the code is received by those that it is supposed to govern. The empirical results are followed by reflection on a number of underlying concerns, by which recommendations for guiding effective implementation of this code and scientific codes of conduct in general will be identified.

\section{Codes of Conduct}

Codes of conduct establish guidelines that indicate what organisations or institutions perceive as 'good' conduct of their members or employees, or which norms and values should guide that conduct. [6] Types, functions and remit of codes vary widely. Frankel [7] describes several functions that codes may have: as an enabling document, a source of public evaluation, a deterrent to unethical behaviour or a support system with the aim to socialize the profession, to enhance public trust, or to adjudicate. Codes usually fulfil several of these functions simultaneously. Derivatives of these functions can be found within codes of conduct for science and engineering: to prevent scientific misconduct, fraud or plagiarism; to hold scientific practitioners to a proper exercise of their duties; to restore or maintain public trust in science and engineering; or to encourage scientists and engineers to engage with their responsibilities towards society.

The importance attached to scientific codes of conduct can be related to several instances of scientific misconduct in recent years, the most notorious cases probably being those of the South Korean biotechnologist Hwang Woo-Suk and German physicist Jan Hendrik Schön, both of whom were accused of fabricating data and fraudulent reporting. These and other cases, which have received wide media attention, have been said to erode public trust in science. If scientists themselves disregard the principles of scientific research, then what does that imply for the credibility of their results? Holding scientists to the proper exercise of their duties thus becomes an issue.

There are several ways to distinguish types of codes [3, 7, 8]. Rappert's classification scheme will be used here. He distinguishes between codes of ethics: "aspirational codes that aim to set standards and alert individuals to certain issues", codes of conduct: "educational or advisory codes that aim to provide guidelines for action", and codes of practice: "enforceable codes that prescribe or proscribe certain behaviour". The Netherlands Code of Conduct studied here is a scientific society code of conduct in Rappert's scheme: an advisory code with the aim to hold scientific practitioners to a proper exercise of their duties, and ultimately to maintain public trust in science. Before going into the results of the interviews, we will briefly describe the code we have taken as our case, how it came into existence, what it purportedly aims to achieve and what stage its implementation has reached. 


\section{The Netherlands Code of Conduct for Scientific Practice as a Case Study}

This code of conduct was established in response to a lecture by Paul van der Heijden, former Rector Magnificus of the University of Amsterdam [9]. He suggested that universities should try to convince society at large of the worth of their efforts by making the principles of scientific conduct explicit in a commonly accepted, generic code of conduct for universities. The Dutch Association of Universities (VSNU) subsequently established the Netherlands Code of Conduct for Scientific Practice which came into force as from 1 January 2005.

The code consists of a preamble, five basic principles including best practices, and a number of dilemmas regarding each of the principles intended to encourage discussion of the code and its limitations (see Table 1).

As originally suggested by Van der Heijden, the principles in the code reflect Robert Merton's four commandments of science commonly known as CUDOS (Communism, Universalism, Disinterestedness and Organised Scepticism) [10]. The code is advisory in nature: the principles are not intended as supplementary judicial rules, and the code does not contain sanction rules or a complaints procedure. It does, however, contain some disciplinary references, providing: "if necessary, ground for admonishment", for which the code refers to the regulations established by the universities and the National Committee for Scientific Integrity Regulations [11]. The VSNU furthermore stipulate that "all universities and their scientific staff will make the necessary effort to familiarise themselves with the content of this code without delay".

\section{Adoption of the Code at Delft University of Technology}

The Executive Board of TU Delft have responded to the VSNU code by explicitly and formally declaring it to be applicable to TU Delft in its Regulations concerning academic integrity. [12] After its formal adoption, the Platform on Ethics and Technology ${ }^{1}$ drafted an implementation plan in 2005 aiming for implementation of the code in all departments of the university. For unknown reasons, however, this process was delayed: the code is still to be implemented in the departments. Implementation has up to now consisted of a debate session on academic integrity, discussion of the code in three different research departments of the university, and a workshop on ethics and technology for PhD students. As a baseline for further implementation activities, a series of interviews was held with researchers at the Department of Biotechnology addressing the following questions: how is this code received by specific communities of researchers? What do they see as its role or function? What are their views opinions about the content of the code and its implementation?

\footnotetext{
1 The Platform for Ethics and Technology focuses on addressing ethical issues in the engineering profession in an early stage. The platform wants to develop practices to address these questions in a systematic manner. To achieve these goals, the platform organizes activities such as workshops and debates about the ethical aspects of the engineering profession at the university, with a special focus on analysis and evaluation of real-life case-studies. http://www.platformet.tudelft.nl/about.html.
} 
Table 1 Principles, definitions and best practices in the code

\begin{tabular}{|c|c|c|}
\hline \multirow[t]{7}{*}{ Scrupulousness } & Principle & $\begin{array}{l}\text { Scientific activities are performed scrupulously, unaffected by } \\
\text { mounting pressure to achieve. }\end{array}$ \\
\hline & Definition & $\begin{array}{l}\text { 1: Having moral integrity; acting in strict regard for what is right or } \\
\text { proper. }\end{array}$ \\
\hline & & 2: Punctiliously exact. \\
\hline & Best practices & Precision and nuance in conducting scientific research. \\
\hline & & Accurate source referencing. \\
\hline & & Acknowledgement of authorship. \\
\hline & & Good mentorship. \\
\hline \multirow[t]{6}{*}{ Verifiability } & Principle & $\begin{array}{l}\text { Science's reputation of reliability is confirmed and enhanced } \\
\text { through the conduct of every scientific practitioner. A scientific } \\
\text { practitioner is reliable in the performance of his research and in } \\
\text { the reporting, and equally in the transfer of knowledge through } \\
\text { teaching and publication. }\end{array}$ \\
\hline & Definition & 1: The quality or state of being reliable. \\
\hline & & $\begin{array}{l}\text { 2: The extent to which an experiment, test, or measuring procedure } \\
\text { yields the same results on repated trials. }\end{array}$ \\
\hline & Best practices & Justification of the selective omission of research results. \\
\hline & & Respect for intellectual property. \\
\hline & & Distinction between transferred knowledge and personal opinion. \\
\hline \multirow[t]{5}{*}{ Reliability } & Principle & $\begin{array}{l}\text { Presented information is verifiable. Whenever research results are } \\
\text { publicized, it is made clear what the data and the conclusions are } \\
\text { based on, where they were derived from and how they can be } \\
\text { verified. }\end{array}$ \\
\hline & Definition & $\begin{array}{l}\text { Capable of being verified. [Verify: to establish the truth, accuracy } \\
\text { or reality of]. }\end{array}$ \\
\hline & Best practices & Accurate documentation of research data and set up. \\
\hline & & Quality of data collection. \\
\hline & & Storage of raw research data. \\
\hline \multirow[t]{5}{*}{ Impartiality } & Principle & $\begin{array}{l}\text { In his scientific activities, the scientific practitioner heeds no other } \\
\text { interest than the scientific interest. In this respect, he is always } \\
\text { prepared to account for his actions. }\end{array}$ \\
\hline & Definition & Not partial or biased: treating or affecting all equally. \\
\hline & Best practices & Giving room to other intellectual stances. \\
\hline & & Impartial assessment of manuscripts. \\
\hline & & Providing an overview of sideline activities. \\
\hline \multirow[t]{5}{*}{ Independence } & Principle & $\begin{array}{l}\text { Scientific practitioners operate in a context of academic liberty and } \\
\text { independence. Insofar as restrictions of that liberty are } \\
\text { inevitable, these are clearly stated. }\end{array}$ \\
\hline & Definition & $\begin{array}{l}\text { The quality or state of being independent. [Independent: not subject } \\
\text { to control by others; not requiring or relying on something else]. }\end{array}$ \\
\hline & Best practices & $\begin{array}{l}\text { Executing commissioned research without interference by the } \\
\text { commissioning party. }\end{array}$ \\
\hline & & Freedom to publish results. \\
\hline & & Identification by name of external financiers. \\
\hline
\end{tabular}




\section{Method}

A representative sample of interviewees was selected based on the principle of maximum variation. Fourteen respondents were interviewed (four professors, two associate professors, three assistant professors and five $\mathrm{PhD}$ students) with roughly equal representation from the various research groups in the Department. Because of the lack of ambiguity in responses, it was not considered necessary to conduct further interviews. Respondents were asked to read the code in advance. Familiarity with this code and other relevant codes, regulations and institutions was assessed. The principles and dilemmas mentioned in the code were discussed in detail and compared with respondents' own views on proper scientific conduct. The interviewees were invited to give their opinion on the need for and relevance of the code whether they thought it was or could be effective in holding scientific practitioners to a proper exercise of their duties, and whether the code encourages ethical reflection. They were asked to name ethical and social aspects of their research and to describe their views on moral responsibility and scientific integrity. Finally, they were invited to propose activities for further implementation. The interviews were recorded and transcriptions were analysed (the quotes below were translated into English by the author, with consent from respondents). The interview results are provided below.

\section{Results}

Familiarity with Codes of Conduct

Two out of 14 respondents had heard about the VSNU code of conduct before the interview. None of them said they use or explicitly refer to it in their work. There was low awareness of other relevant codes as well: half of the respondents had not heard of any of the codes or initiatives mentioned. Best known were the Code of Conduct for engineers from the Dutch association for engineers and engineering students (KIVI/NIRIA), and the Code of Conduct for Biotechnologists from the Netherlands Biotechnology Foundation. Four out of fourteen said they had heard about the Platform on Ethics and Technology. One respondent was familiar with the Regulations concerning academic integrity at TU Delft, none had heard from TU Delft's Committee on Academic Integrity (see Figs. 1 and 2).

\section{Content of the Code}

\section{General Views and Opinions}

Eight respondents thought that a code of conduct could in principle be a useful instrument to enhance awareness of what good scientific teaching and research entails:

There are many points in there, and, in that sense, when we're honest as a profession, in fact, broadly, science in general, there are, well, quite a few problems in various institutes, right? (R02). 


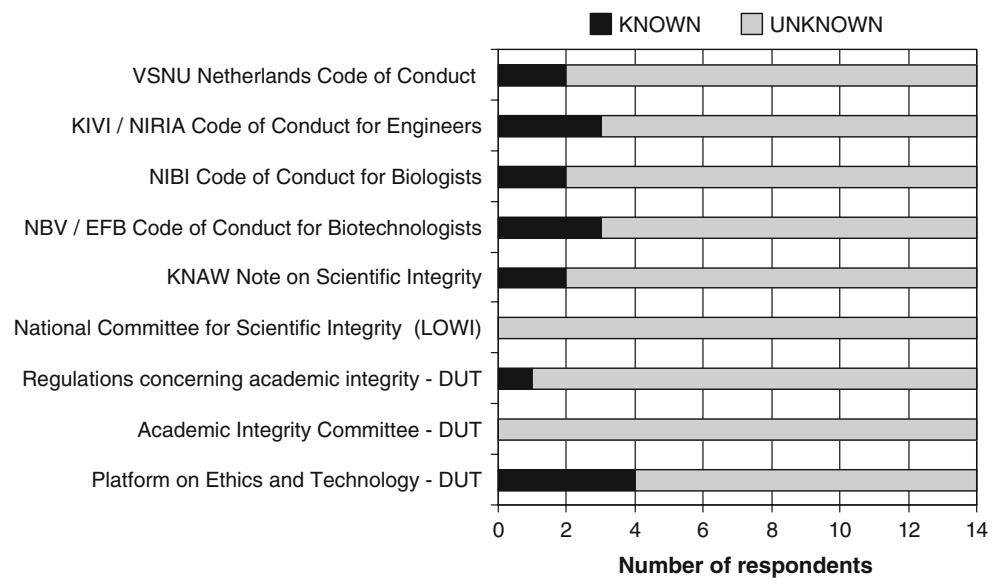

Fig. 1 Awareness of codes and committees—per code

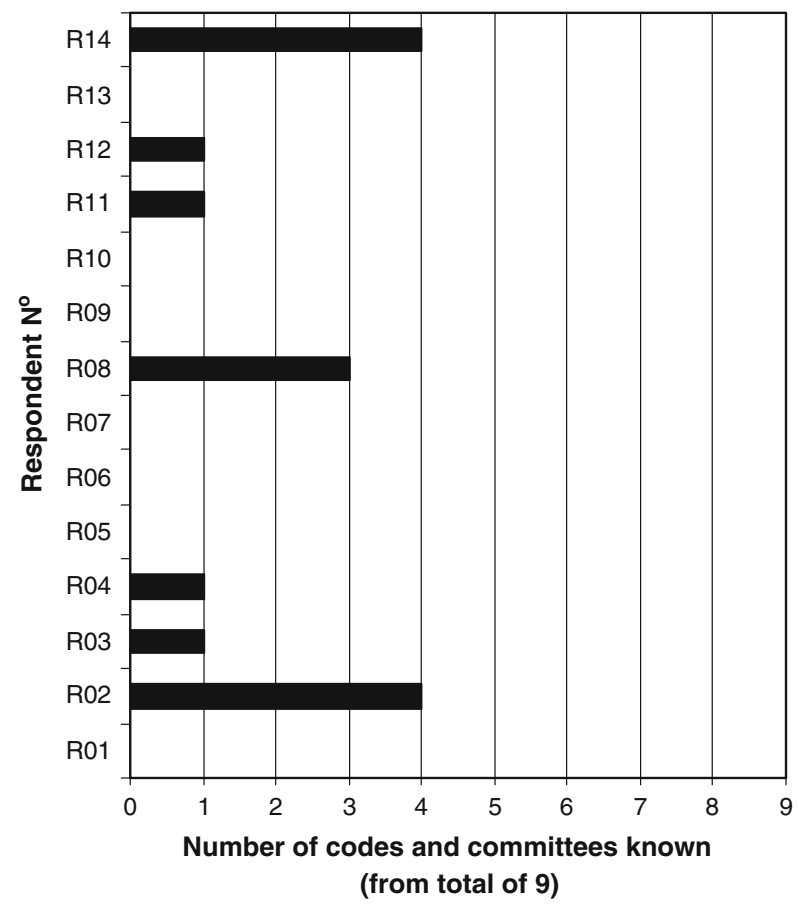

Fig. 2 Awareness of codes and committees-per respondent

Seven interviewees said that researchers should become more aware of the ethical aspects of their work. They did, however, not see how the code of conduct $a s$ such would enhance awareness. Six respondents were very sceptical about the use and function of this code: 
I don't know what this code will add to the diarrhoea of codes that is already there. ... It almost seems as if everybody wants to have their own code ... instead of looking whether there already is an existing code that we might hook on to (R08).

Even though most interviewees were less sceptical, eleven of them commented spontaneously that the code was 'forcing an open door' (Fig. 3):

I think it's all a matter of forcing an open door ... This is just another, a group of people that liked establishing a code so they'd have something to do, at least that's how I see it ... (R12).

\section{The Principles and Dilemmas}

Respondents were all asked for their opinion on the principles and dilemmas within the code. The principles did not seem to surprise anyone; they were seen to reflect the norms and values within science rather well. Interviewees did recognise potential dilemmas if these principles are to be applied in practice. It is interesting to note that although all respondents stressed that their colleagues generally follow the principles of scientific conduct and do not need to become more aware of them, they all gave several examples of dilemmas encountered either personally or indirectly when asked about their personal experience.

As can be seen from Fig. 4, each of the dilemmas elicited responses, scrupulousness and verifiability being the least contested. Some respondents commented on personal working styles and relations between senior researchers and their research students in relation to scrupulousness, or the source of research data in relation to verifiability.

Significantly more comments were related to the principle of reliability. They concerned the acquisition, interpretation and presentation of research data, results and conclusions:

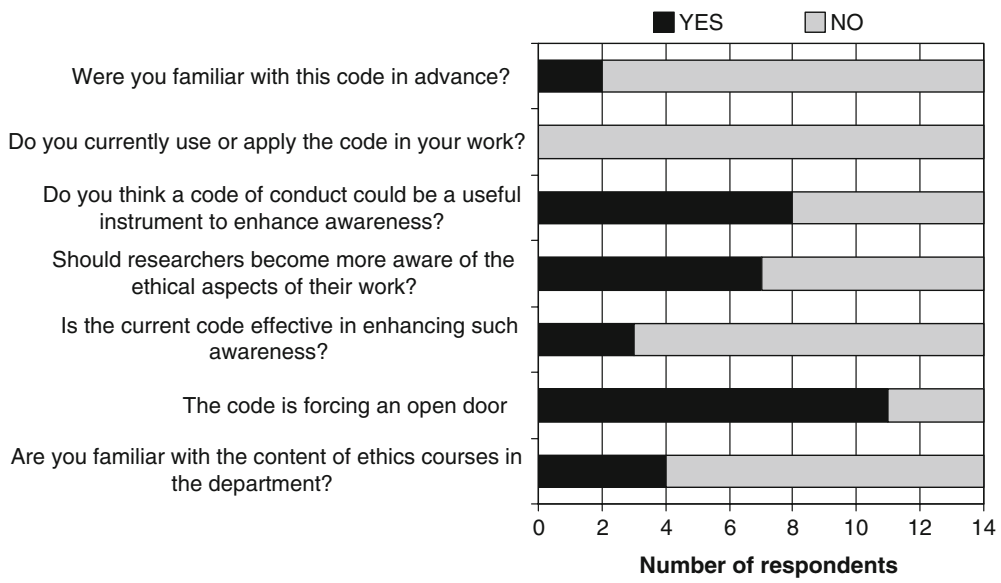

Fig. 3 Respondents' opinions on the relevance of the code of conduct 


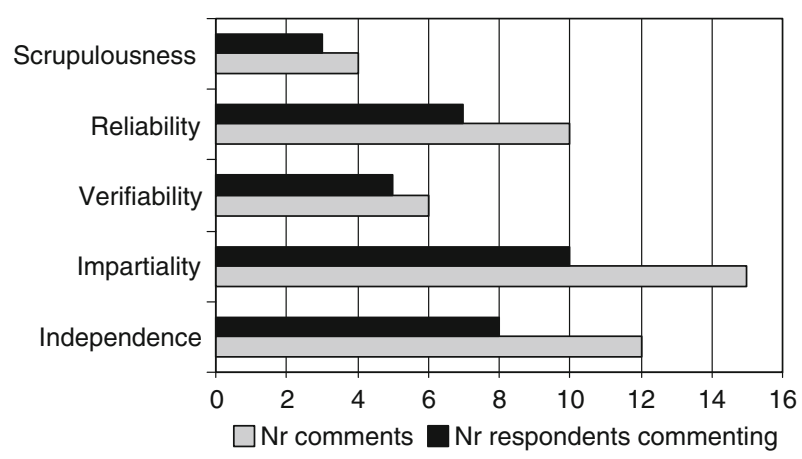

Fig. 4 Respondents' comments on the principles and dilemmas

I think that as a researcher, of course you always try to publish the good and nice results, and results that are less good, well, you keep them back, or you try to work around them in a nice way (R05).

Most of the comments (15 in total) were on the principle of impartiality. They were related to biased assessments in peer review processes and biased presentation of research data and conclusions:

Let's say you're doing research that is paid for by a company, and then you can do decent publications, and then you can't, in the media for example, then you're not going to say anything improper about the company, because then... that's not very smart. But okay, then you can still do pure science, that is another matter (R03).

There were 12 comments on the principle of independence, concerning contract research and balancing scientific interests with the commissioning party's interests:

Well I'm sorry, but if a company offers us three hundred thousand to do research... of course we'll choose things that are academically interesting and we're not going to do purely commercial research... but if we would choose something purely fundamental ... then the company will say like: hello what good is this to us ... or something that is more directed towards application and which they could actually use, well then it's rather clear which way that will go, because we consult together very often [within the research group] ... of course we talk about this a lot ..., but that's quickly a very easy decision (R13).

Five respondents also commented spontaneously that the principles of impartiality and independence were untenable in the current day research climate, due to major changes in the financing of research:

Impartiality, and independence, you see that so often in this work ... because I cooperate closely with [name of company], ... certain research results are not good for the innovation, you have to publish those as a scientist, but I often discuss this with [name of company] ... because they'd rather not have it ... 
Things appear and risks that you actually wouldn't want to bring out into the open, and how should researchers deal with those, etcetera. This happens more and more often, with these big, privately financed projects and those sorts of things. That has to be thought through (R09).

\section{Implementation of the Code: Applying the Principles in Practice}

The responses above show that although researchers perceive the principles within the code to be almost self-evident, the application of those principles in practice may lead to morally complex situations. The principle of reliability may seem clear enough at first reading, but when exactly does the omission of a data point become morally reprehensible? Similarly, the example provided with the principle of impartiality shows the difficulty of maintaining that principle in the context of private funding. These are just a few of the examples provided that point to the potential moral complexities involved in the application of the principles. Enhancing awareness of how the principles relate to practice thus seems appropriate. On the other hand, most respondents did not see how the code as such would achieve that aim. Why do they consider the code to be ineffective? Interviewees provided several answers with remarkable agreement. Their comments were related to visibility, enforcement, the separation of general ethical principles from daily practice, and responsibility. Each of these issues will be discussed in turn.

\section{The Code has Largely Remained Invisible}

The most obvious reason for not having an effect was that the code is still unknown to the majority of researchers. As can be seen from Fig. 2, most respondents were not aware of the existence of the code, nor of the institutions involved. This could be due to a lack of interest from the side of the scientific community, but it was also connected with a lack of communication from the side of the institutions:

... two things, so that's, well, just never needed it... but also, invisible, these institutions, to put it that way... So it works in both directions, so call it disinterestedness, or no need, or don't have the time for it, but the institutions are themselves invisible as well (R02).

\section{Due to the Voluntary Nature of this Code, Enforcement was Seen to be Problematic}

Specifically because of the fact that this is an advisory code without the possibility of enforcement through disciplinary measures, some people doubted whether it would hold scientists to a proper exercise of their duties:

... you can't do anything with it, because when there is someone who doesn't behave that way ... there are no sanctions to beat him around the head with or anything. To do that you've got other codes and guidelines, and... Then I'm thinking to myself, yeah, okay. What a pity (R12). 
Several respondents indicated that adherence to the code is not so much determined by knowledge of the principles, but rather in the willingness to apply them:

I think scientists who don't ehm, apply the code, know very well that they don't apply it, and maybe even do it on purpose, because they, well eh, to boost their career or I don't know what (R13).

If scientific practitioners cannot be held accountable on the basis of this code, it may be ineffective in holding them to the proper exercise of their duties. What to do in case of an observed breach of the code? What disciplinary measures can or will be taken?

\section{It is Unclear How the Principles of a Generic Code Relate to Daily Practices}

The previous point could become obsolete once the code has become generally accepted, and when it is clear what the principles mean in actual practice. Most interviewees, however, did not see how the principles were meant to guide conduct in practice. They considered the code too general to apply:

Such a code aims to be all-encompassing, by which it remains relatively vague, and it misses the specific points that people work with. They are a part of it, they fall within that big cloud of what the code deals with, but it doesn't give an answer to how I should act in this specific situation (R14).

The wish to establish a code of conduct that applies to all scientific practitioners allied with a university in the Netherlands seems to have come at a cost. These five principles have to apply to a range of fields of research, from the history of ancient Greek pottery to chemical engineering, and from theoretical physics to the social studies of science. But practitioners in different fields of research have agreed to different norms and values, due to differences in the nature of the research topics, approaches, methods, and results. Principles of conduct differ across universities, especially between academic and technical sciences. In biotechnology, where there is often close cooperation between scientists, engineers and industry, the principles of impartiality and independence are much harder to maintain than in less application-oriented fields like philosophy. Such differences occur even in closely related fields: reproducibility might be a key aspect of the principle of reliability in organic chemistry, but it is much less so in enzymology, because of the inherent instability of enzymes. In order to find the common ground between disparate fields of research, the specificities of particular fields of research have remained outside the scope of the code. At that point, the relation between the code and working practices may become very abstract and difficult to grasp for individual practitioners.

\section{Moral Principles Cannot be Separated from Working Practices}

A related but different point was put forward in relation to the way moral principles in the code were presented as the sole criteria for good scientific practice. Several 
respondents were dissatisfied with the way the moral principles have been uncoupled from actual working practices:

I think this describes quite sharply, like I said, the issues... But it's out of context. ... Science is an odd business, right, it's in fact all about... being acknowledged, being recognized... But why then do we still have those stubborn guys, that, let's say, are just issuing orders from their little ivory tower? Why? Because they do deliver scientifically, as regards to content, scientifically superb quality ... that's crucial, so, scientific quality is first ... So that's what I would like to see clearly in here... Because in effect you want to prevent ... that social aspect to be torn from its context, right? (R02).

\section{Concerns about Individual Responsibility}

A final, major concern with the code had to do with the specific nature and conception of responsibility within the code. The code was perceived to put the burden of responsibility entirely on the individual researcher. This focus on individual responsibility irritated some respondents; it was seen as a lack of trust in scientists:

... the researcher can feel like eh, not reliable then. Because if somebody checks him, he thinks like ... it is a kind of interfering with my freedom, and somebody doesn't believe that I'm doing good work (R06).

What the effect will be, once they start applying it? I think we'll all feel eh... at least, I would feel very much accused... (R12).

Responsibility was rather seen as something that is distributed:

It's a distribution of all kinds of responsibilities... this code was also very much written for one person, how he should act, but it leaves out how responsibility is distributed, just like in peer review where you've got the researcher himself, the co-authors involved, the colleagues he works with, the institute, and then even the editor and the reviewers (R14).

Several respondents also referred to the 'system' in which researchers have to operate as a potential cause of misconduct:

Well, you have a conflict sometimes, that is that, universities like to hold accountable, on numbers of publications for example, on all kinds of parameters... And if that pressure grows too strong, then the urge to publish the same thing twice... or to, well, salami-slicing-tactics in publications, grows considerably (R08).

\section{Discussion}

In summary, although the code has been established in response to a perceived need to discuss and reflect on the principles that govern scientific practices, respondents 
identified several issues that make the code ineffective in achieving its aim as a guideline for the individual scientist: most scientists are not aware of its existence, there is no means of enforcement, it is too general to apply in practice, the moral dimensions of research decisions should not be separated from the practical context, and the division of responsibility is perceived as unfair and unrealistic.

\section{Suggestions for Implementation}

What recommendations for further implementation of this particular code of conduct can be derived from these observations? The following suggestions will be discussed in greater detail below: the code first of all needs to become more visible and discussions on the principles need to be stimulated; the code of conduct should be integrated with existing codes of practice; and the specific conception and attribution of responsibility should be reconsidered.

\section{Increasing Visibility, Stimulating Discussion}

The first step in the implementation process should be that researchers become more familiar with the code. Respondents were asked what they would do if they were given the assignment to address ethical and social aspects in the department themselves (see Table 2).

They said the code itself needs to become more visible, for instance by making copies of the code available for all students and staff, or by attaching the code to the employment contract.

When everybody takes the time to read it ... you'll initiate a discussion, and even though the discussion will be about what nonsense have you read this... why are they bothering us with this now... Then they'll still have colleagues around them, who can say like yeah, but I think point 3.6 is rather interesting, so to say... And once you get that discussion going, then it will come alive with people... (R09).

Apart from visibility, respondents also agreed that the code should become more tangible if it is to enhance awareness of what good scientific research entails. The suggestion mentioned most often (seven times in total) was to initiate discussion sessions on real-life cases of ethical dilemmas and, importantly, ways to address them:

... if one simply provides a few examples, like this is what happened there, and this is what happened here... That might speak more to the imagination, that is relevant... that has to do with the university specifically (R10).

There may be a social desirability bias in these answers: who would deny that ethics is important? Looking at the actual involvement of scientists with the ethical aspects of research, few of the respondents were familiar with the content of the ethics courses in their department, or had been directly involved in ethics-related activities (see Fig. 3). But this lack of familiarity might also have to do with ethics being perceived as external to scientific practices. Once the ethical aspects of 
Table 2 Suggestions for implementation by respondents $(n=14)$

\begin{tabular}{|c|c|c|}
\hline & & $\begin{array}{l}\text { No. of times } \\
\text { suggested }\end{array}$ \\
\hline \multirow[t]{7}{*}{ Stimulate a discussion } & Discussion session on real-life cases of ethical dilemmas & 7 \\
\hline & Plenary session with specific points as introduction & 1 \\
\hline & $\begin{array}{l}\text { Discussing the reasons, motivations, intentions behind } \\
\text { the code }\end{array}$ & 1 \\
\hline & $\begin{array}{l}\text { Discuss the shift from government funding to private } \\
\text { funding }\end{array}$ & 1 \\
\hline & Discuss in board meeting and in the lab & 1 \\
\hline & Convince professors of the need for such a code & 1 \\
\hline & Offer lectures or a workshop on ethics & 1 \\
\hline \multirow[t]{3}{*}{ Increase visibility } & Make copies of the code available for everybody & 5 \\
\hline & Attach the code to the employment contract & 3 \\
\hline & Make visible on the university homepage & 1 \\
\hline \multirow{2}{*}{$\begin{array}{l}\text { Integrate with existing } \\
\text { rules }\end{array}$} & Integrate in annual assessment cycle & 2 \\
\hline & Integrate with lab rules & 1 \\
\hline \multirow[t]{2}{*}{ Use in education } & Courses with relevant, specific cases & 2 \\
\hline & Use in education of bachelors, masters and $\mathrm{PhD}$ & 1 \\
\hline \multirow[t]{4}{*}{ Further measures } & Appoint confidential advisors at the university & 1 \\
\hline & Integrate in the annual social report & 1 \\
\hline & Conduct ethical parallel reseacrh & 1 \\
\hline & Create a personal oath & 1 \\
\hline
\end{tabular}

relevance to scientific practice are discussed, there does seem to be a genuine desire to engage in discussion. The challenge is therefore to remain close to the lived morality of researchers. Several research groups in the department are currently constructing 'bottom-up' solutions for addressing issues of impartiality and independence in an increasingly privately funded research context. It is those kinds of discussions, those kinds of questions that should be the focus of ethical deliberation. How to make judgments when the principles prescribe conflicting courses of action? The principles need to be discussed openly, and especially where they are vague of contradictory.

\section{Integrating the Code of Conduct with Existing Rules of Practice}

Detailed discussion of concrete cases may assist in clarifying how the principles apply to daily practice. But this does not mean researchers will be held to a proper exercise of their duty. Due to the voluntary nature of the code, enforcement remains an issue:

If people really don't want to, and say like, yeah, I'm following all this, but in fact aren't doing a lot of these things, then you'll need some very concrete indications to say like, hang on, it says so there, and you're doing it very differently... And it's the question to what extent one can enforce it (R11). 
If the aim of the code is to guide individual researchers in their behaviour, then rules for conduct need to become a part of the day-to-day working codes of practice. Scientists are already following existing codes of practice: lab rules, GM regulations, safety regulations and so forth. Contrary to the current status of the code, these are seen to be central do to research properly. They are required to make experiments work, or even to be able to do experiments in the first place. But the code of conduct is considered peripheral, and not perceived as related to their work. If the ethical principles can be embedded into the ordinary working methods, there is a greater chance of getting the issues addressed within the group. The code of conduct would then be more than a pie in the sky, a statement of the values universities hold high without reference to daily research practices. Several respondents also proposed to integrate the code with existing rules and regulations, such as the lab rules with which everybody is familiar.

\section{Rethinking Responsibility}

The dilemmas provided above underline the need to enhance awareness of the principles of good scientific research and the responsibilities of individual scientists. But when the responsibilities of individual scientists are isolated from the 'system' in which researchers have to operate, potential underlying causes of scientific misconduct remain hidden. Swierstra and Jelsma [13] have shown that assigning full responsibility to individual researchers is unrealistic. It is often hard to point to a single researcher in the event of unwanted outcomes. Science is first of all a collective endeavour, and this should be reflected in the notion of responsibility. As Mark Frankel [7] writes:

... promoting ethical conduct does not, and should not, have to be solely the responsibility of the individual ... The professional group, as a more visible, more stable, and more enduring entity, has a collective moral responsibility that is nondistributive; that is, a responsibility borne by the profession as a whole independent of the ethical posture of its individual members.

There are potential conflicts between the principles and the research context in which scientists have to operate: increasing pressures to achieve, the shift in financing structures, 'subjective' elements within the peer review process and conflicting expectations from different parties may all give rise to morally problematic behaviour. To prevent individual researchers from becoming the scapegoat for morally problematic situations that are beyond their powers of influence, the distribution of responsibilities therefore, deserves attention in the implementation process as well.

There was some concern with respondents that the true cause for this code was not to encourage researchers to reflect on their responsibilities, but rather to evade responsibility in the higher echelons:

Yeah, where is this coming from so all of a sudden? Scientific research is nothing new, it's not the latest fashion or anything, but now all of a sudden, well, certainly in the field I'm working in, which has been in existence for 
about thirty, forty years... and suddenly there is this code. How did that originate, what initiated that? (R05).

At the moment, it is difficult to say what the true intentions behind this code are. Why have the VSNU and the Board of TU Delft wanted to implement the Code? What does the Board expect to achieve? How does the board see its own responsibility in these matters? There is very little information available on the motivation for establishing the code and commitment to implement it. But if researchers cannot be convinced of the fact that the code is meant to encourage responsibility, distancing might occur. The code then becomes a strategic instrument to delegate responsibility instead of taking it, leading to a situation where the management of the university points to the individual's personal responsibility, and the individual scientists point to their relative lack of freedom. Apart from the individual responsibility of researchers to follow the principles of scientific conduct, there is a collective responsibility to resolve possible pressures in the 'system' that may invite scientific misconduct such as linking possibilities of promotion to the number of publications, holding researchers accountable for their own budget or the increasing competition among researchers.

Scientists can and should be held responsible for their actions, but it has to be acknowledged that their responsibility is distributed and role-dependent. More robust ways of addressing the complex relationship between individual responsibility and institutional or collective responsibility can be found in the engineering ethics literature [14-16].

\section{Reconsidering the Principles of Scientific Conduct}

Although most respondents confirm that researchers in the department should become more aware of the ethical aspects of scientific practice, they do not consider the code as such a useful tool to reach that objective. The principles first need to become better integrated in daily practice. The main interview results corroborate findings in the business and research ethics literature [17-20], and may inform further implementation activities of the Platform on Ethics and Technology. Despite the fact that most of these results apply to the Department of Biotechnology specifically, two general observations apply to the implementation of codes of conduct across the board: the difficulty of maintaining Merton's principles as a guide for good scientific conduct in a changing research context, and the complexities of explicitly addressing ethical issues in research cultures.

Echoes of Merton's CUDOS can be heard in many contemporary scientific society codes of conduct, either literally, as is the case with the VSNU code of conduct, or in spirit, when the code focuses on the neutrality, objectivity and critical attitude of the individual researcher. But research practices in several areas of research have changed quite drastically in relation to the time when Merton devised those principles. First of all, most modern-day science has become 'Big Science', performing large-scale research programmes that require considerable investments. Second, science and technology have become increasingly application-oriented. Especially in such new disciplines as genetics, biotechnology and nanotechnology, 
the development of new knowledge is intimately connected to the application of that knowledge in new tools, materials, products and devices. Third, government funding has decreased in recent years, while private funding has increased, leading to a more important role for industry in setting research policies and a further focus on knowledge production in a context of application. One respondent remarked:

I think it also has to do with the fact that the whole financial infrastructure of universities has changed in recent years. ... I know many professors who said like private funding is dirty, you shouldn't touch that, ... you'll become a puppet of companies. Well nowadays ... I think those who say that will be stoned to death immediately, so to speak. So that has changed completely. ... You want to continue your research anyway, and that means eh, when the tide turns, one needs to replace the beacons (R11).

This shift in practices goes by many names like Mode 2 science, post-normal science, or post-academic science (for a review, see Hessels and Van Lente [21]). The point here is that neither scientific nor engineering codes of conduct quite cover the new types of research practices that have begun to emerge in the aforementioned areas of research. As the interview results imply, the principles of impartiality and independence for instance can hardly be maintained in privately funded, application-oriented settings. This also puts respondents' concerns about individual responsibility in perspective: reconsideration of the principles of scientific conduct is a collective endeavour per se. These issues cannot be solved by individual researchers alone.

The second observation relates to the ways ethical issues are dealt with in research cultures. Respondents did not always see how the ethical aspects of research relate to their own work:

Scrupulousness, reliability, independence, ... ..... Ehm, oh dear, ... ... Well, the point is, we, I, I am so far away from this, or, well, far away, ... ... Ehm... I can... I lead my own investigation... and I am fully autonomous in that, so I have very little to do with other people. ... The work I do, eh, has very little to do with society (R05).

Researchers in the department generally do not discuss the ethical aspects of research explicitly. When asked how moral dilemmas are addressed within the group if and when they occur, one respondent commented:

In general... those things aren't on the table that explicitly. ... Like with many other things that's not a separate topic in daily conversations with colleagues.

Yeah, it just happens in between... implicitly (R01).

The perceived need to establish codes of conduct could be interpreted as a response to these two observations: the need to rethink the responsibilities of scientists and the principles of scientific conduct within research cultures that are not accustomed to the explicit discussion of moral principles. If that sounds like a reasonable suggestion, then initiatives that facilitate the discussion and reconsideration of the principles might in fact be more appropriate than the reiteration of those principles in codes of conduct. 


\section{Conclusion}

The veritable explosion of scientific codes of conduct indicates the importance attached to reflection on the role of scientific expertise, and given the impact of scientific research on society, addressing the moral responsibilities of scientists seems to be warranted. Coding can be a useful exercise to open up discussion on the principles that govern scientific conduct. The Netherlands Code of Conduct for Scientific Practice was established to hold scientific practitioners in the Netherlands to a proper exercise of their duties. The interview results, however, point out that effective implementation of the code of conduct still offers many challenges: as a tool for the individual scientific practitioner, the code leaves a number of important questions unanswered. The code should become more visible and better discussed and integrated with research practices. Furthermore, if it is to be more than an instrument used for delegating responsibility in order to go back to 'business as usual', the conception of responsibility in the code needs to be reconsidered. As to the implementation of codes of conduct in general, attention needs to be paid to recent changes in the research context: the principles of good scientific conduct themselves may need to be revisited and the capacity to address moral issues within research cultures should be addressed. In conclusion, there is more at stake than merely holding scientific practitioners to a proper exercise of their duties; implementation of scientific society codes of conduct also concerns the further motives and value commitments that gave rise to their establishment in the first place.

Acknowledgements The researchers at the Department of Biotechnology are gratefully acknowledged for their cooperation. Many thanks to Ibo van de Poel, Erik Fisher and the members of the Working Group on Biotechnology and Society in Delft for helpful comments on earlier versions of this text. This project was carried out within the research programmes of the Centre for Society and Genomics and the Kluyver Centre for Genomics of Industrial Fermentation which are part of the Netherlands Genomics Initiative/Netherlands Organization for Scientific Research.

Open Access This article is distributed under the terms of the Creative Commons Attribution Noncommercial License which permits any noncommercial use, distribution, and reproduction in any medium, provided the original author(s) and source are credited.

\section{References}

1. Global Ethics Observatory, UNESCO http://www.unesco.org/shs/ethics/geobs. Accessed 13 October, 2008.

2. Lentzos, F. (2006). Managing biorisks: Considering codes of conduct. The Nonproliferation Review, 13(2), 211-226. doi:10.1080/10736700601012045.

3. Rappert, B. (2007). Codes of conduct and biological weapons: An in-process assessment. Biosecurity and Bioterrorism: Biodefense, Strategy, Practice, and Science, 5(2), 145-154. doi:10.1089/bsp. 2007.0003.

4. Evers, K. (2001). Standards for ethics and responsibility in science: An analysis and evaluation of their content, background and function. The International Council for Science: The Standing Committee on Responsibility and Ethics in Science (SCRES). Available at: http://www.icsu.org/ Gestion/img/ICSU_DOC_DOWNLOAD/218_DD_FILE_Background_1.pdf. Accessed 13 October 2008. 
5. VSNU. (2005). The Netherlands code of conduct for scientific practice: Principles of good scientific teaching and research. Available at: http://www.vsnu.nl/web/show/id=54033/langid=43. Accessed 13 October 2008.

6. Royakkers, L., van de Poel, I., \& Pieters, A. (Eds.). (2004). Ethiek \& Techniek. Morele overwegingen in de ingenieurspraktijk. HBuitgevers: Baarn.

7. Frankel, M. S. (1989). Professional codes: Why, how, and with what impact? Journal of Business Ethics, 8(2-3), 109-115. doi:10.1007/BF00382575.

8. Hogenhuis, C. T. (1993). Beroepscodes en morele verantwoordelijkheid in technische en natuurwetenschappelijke beroepen. Een inventariserend onderzoek. Den Haag: Multidisciplinair Centrum voor Kerk en Samenleving/Ministerie van Onderwijs en Wetenschappen.

9. Van der Heijden, P. F., \& de Rooy, P. (2004). Publiek vertrouwen/Groot gelijk. Drie pleidooien 'Aan het volk van Nederland'. Amsterdam: Amsterdam University Press.

10. Merton, R. K. (1942). The normative structure of science. In R. K. Merton (Ed.), The sociology of science: Theoretical and empirical investigations (1973). Chicago, IL: University of Chicago Press.

11. KNAW/VSNU. (2001). Notitie Wetenschappelijke Integriteit: Over normen van wetenschappelijk onderzoek en een Landelijk Orgaan voor Wetenschappelijke Integriteit (LOWI). Available at: http://www.knaw.nl/publicaties/pdf/20011082.pdf. Accessed 13 October 2008.

12. Delft University of Technology. (2005). Regulations Concerning Academic Integrity at Delft University of Technology. Available at: http://www.tudelft.n1/live/pagina.jsp?id=53cc1557-c2134723-92bb-b6d7a4dedf98\&lang=en. Accessed 13 October 2008.

13. Swierstra, T., \& Jelsma, K. (2006). Responsibility without moralism in technoscientific design practice. Science, Technology \& Human Values, 31(3), 309-332. doi:10.1177/0162243905285844.

14. Mitcham, C. (2003). Co-Responsibility for research integrity. Science and Engineering Ethics, 9, 273-290. doi:10.1007/s11948-003-0014-0.

15. Miller, S., \& Makela, P. (2005). The collectivist approach to collective moral responsibility. Metaphilosophy, 36(5), 634-651. doi:10.1111/j.1467-9973.2005.00397.x.

16. Consoli, L. (2008). The intertwining of ethics and methodology in science and engineering: A virtueethical approach. Interdisciplinary Science Reviews, 33(3), 233-242. doi:10.1179/174327908X 366923.

17. Coughlan, R. (2005). Codes, values and justifications in the ethical decision-making process. Journal of Business Ethics, 59, 45-53. doi:10.1007/s10551-005-3409-9.

18. Lere, J. C., \& Gaumnitz, B. R. (2003). The impact of codes of ethics on decision making: Some insights from information economics. Journal of Business Ethics, 48, 365-379. doi:10.1023/B: BUSI.0000005747.37500.c8.

19. Raiborn, C. A., \& Payne, D. (1990). Corporate codes of conduct: A collective conscience and continuum. Journal of Business Ethics, 9, 879-889. doi:10.1007/BF00382911.

20. Nitsch, D., Baetz, M., \& Christensen Hughes, J. (2005). Why code of conduct violations go unreported: A conceptual framework to guide intervention and future research. Journal of Business Ethics, 57, 327-341. doi:10.1007/s10551-004-8203-6.

21. Hessels, L. K., \& van Lente, H. (2008). Re-thinking new knowledge production: A literature review and a research agenda. Research Policy, 37, 740-760. doi:10.1016/j.respol.2008.01.008. 